\title{
The Impacts of Knowledge Management Practices on Innovation Activities in High- and Low-Tech Firms
}

\author{
Kris M. Y. Law, Deakin University, Australia \\ (iD) https://orcid.org/0000-0003-3659-0033 \\ Antonio K. W. Lau, Kyung Hee University, South Korea \\ Andrew W. H. Ip, University of Saskatchewan, Canada \\ iD https://orcid.org/0000-0001-6609-0713
}

\begin{abstract}
This paper presents an empirical study on how knowledge management practices and innovation sources affect product innovation performance among the 152 manufacturers in the low- and hightech industries in China. The results indicate that external innovation sources are positively correlated with innovation activities and new product performance. Intellectual property (IP) and knowledge management practices (KMP) are positively correlated with innovation activities, and KMP is positively correlated with innovation sources. The dual effect of KMP shows its indispensable effect on the new product development for both high-tech and low-tech firms, but for low-tech firms, such effect is relatively weak. This empirical study shows that IP management is critical to high-tech but not low-tech firms. The authors also found that, for innovation activities, low-tech depends on the external sources of innovation whilst high-tech firms do not.
\end{abstract}

\section{KEYWORDS}

China Manufacturers, High-Tech, Knowledge Management Practices, Low-Tech, Product Innovation, Sources of Innovation

\section{INTRODUCTION}

Sourcing and managing knowledge are critical for product innovation (Law, Lau, \& Ip, 2019; Hernandez-Vivanco, Bernardo, \& Cruz-Cázares, 2016). Knowledge for innovation in both tacit or explicit forms can come from different sources through internal and external innovation activities, such as up-to-date publications, databases or information from business partners (Cassiman \& Veugelers, 2006). Innovation relevant studies have focused on the economic outcomes, innovation actors, the quantitative measurement of innovation performance, and the effectiveness of funded initiatives (Yam, William, Tang, \& Lau, 2011).

Literature about product innovation is generally focusing on high-tech industries (Chai, Yap, \& Wang, 2011), and not much on low-tech industries or the comparison between those (Martinez, Zouaghi, \& Garcia, 2017). Innovation activities can be found in high-tech and low-tech industries; however, the global trend focuses on high tech developments. Non-high tech industries are mostly ignored in these innovation activities though they contribute significantly to the market (Abbate

DOI: 10.4018/JGIM.20211101.oa41

This article published as an Open Access article distributed under the terms of the Creative Commons Attribution License (http://creativecommons.org/licenses/by/4.0/) which permits unrestricted use, distribution, and production in any medium, provided the author of the original work and original publication source are properly credited. 
et al., 2020; Law, Lau, \& Ip, 2019; Brookfield, Liu, \& MacDuffie, 2008). High-tech companies involve higher technological complexity levels and extensive R\&D activities and are characterized by product innovations. In contrast, low-tech companies are characterized by the process, organizational and marketing innovations with weaker internal innovation capabilities and dependent on external embodied knowledge acquisitions (Pavitt, 1984). Scholars reported that they have distinctive contexts for internal and external knowledge capabilities and collaboration (Buenechea-Elberdin et al., 2018; Berchici et al., 2013; Bender 2008; Heidenreich, 2009). To improve innovation performance, low-tech firms, for example, look for R\&D human capital, while high-tech firms invest in R\&D expenditures (Zouaghi et al., 2018). Due to low R\&D investment, low-tech firms usually lack the absorptive capacity to take advantage of external scientific knowledge for product innovation effectively but are good to acquire other types of external knowledge (e.g. social science knowledge from local universities) for process and marketing innovations (Abbate et al., 2020; Flor et al., 2021). In view of this, the knowledge management for high-tech and low-tech firms should be different, but there is less attention to their differences in literature (Flor et al., 2021; Trott and Simms, 2017).

Due to the lack of understanding of the low-tech innovation processes, it is essential to study the innovation activities for both types of industries for offering the proper instruments to support their industrial development in terms of innovation activities and knowledge management practices (KMP) (Martinez, Zouaghi, \& Garcia, 2017; Jensen, Johnson, Lorenz, \& Lundvall, 2007; Hirsch-Kreinsen, 2008; Heidenreich, 2009). Cooperating with internal and external parties is commonly seen among firms to create new knowledge (Cassiman \& Veugelers, 2006). Especially, a high-tech firm usually uses sophisticated information management systems to facilitate knowledge sharing and acquisition (Lyu \& Zhang, 2017; Xi, Zhao, \& Na, 2019). Thus, the KMP for low-tech firms may be different from that of high-tech firms. However, to our best knowledge, a comparative empirical analysis of KMP and sources of innovation for high-tech and non-high-tech firms is a few in China manufacturing.

This main objective of this research is to study the impact of knowledge management practices (KMP) on product innovation performance. This paper presents an empirical study on the exploration of how knowledge management practices (KMP), the sources of innovation, and the use of intellectual property protection affect product innovation performance in China, comparing them with low- and high- tech industries. One of the critical challenges for business owners in a knowledge-based economy is how organizations can create value and present appropriate performance of their products and services by exploring and exploiting different layers of knowledge to obtain strategic results of the business (Valmohammadi, Sofiyabadi, \& Kolahi, 2019; Novak, Breznik, \& Natek, 2020). The new product innovation processes involve a high level of knowledge management practice, including the storage and diffusion of knowledge. The knowledge sharing between organization members through open communication and cross-functional teams could help accomplish tasks on time and more effectively, especially for highly innovative projects. However, the impact of knowledge management practice (KMP) on new product performance remains unclear, especially how KMP is affecting the innovation activities which drive the new product development (Akgün, Byrne, Keskin, \& Lynn, 2006; Akgün, Lynn, \& Yilmaz, 2006; Akgün, Byrne, Keskin, \& Lynn, 2005).

The study, therefore, attempts to explore the influence of innovation activities on new product performance by considering the effect of KMP and the use of IP on innovation activities. The motivation of this empirical study is in research on the moderating effect of KMP in the relationship between innovation activities and new product performance. More importantly, this study also examines if there exists a significant difference between high-tech and low-tech firms regarding the effects of KMP on product innovation performance, thus contributing to the understanding of how R\&D investment affect knowledge management (Flor et al., 2021; Abbate et al., 2020; Trott \& Simms, 2017; Heidenreich, 2009). As low-tech industries, similar to high tech ones, deliver economic growth and development for countries, this is important for scholars to identify how their firms innovate new products (Trott \& Simms, 2017). However, according to our literature search, such studies are 
uncommon in China manufacturing and other advanced economies. The focus on high- and low- tech companies and their comparison in China's context is the novelty of this study.

\section{THEORETICAL BACKGROUND}

\subsection{Influence of Innovation Activities}

In the past two decades, various inputs to innovation systems, such as innovation capacity and activities, and innovation clusters, have been studied extensively (Love \& Roper, 2015; Hekkert, Suurs, Negro, Kuhlmann, \& Smits, 2006; Wang, Lin, \& Li, 2010; Breznik, 2016), as well how innovation activities and other factors affect competitiveness and performance (Yam, William, Tang, \& Lau, 2011) and more on the impacts of innovation (OECD, 2010). However, it is still unclear how innovation-related activities impact the new product performance and context-specific (Duran, Kammerlander, Van Essen, \& Zellweger, 2016). Further, the direct impacts of motivators and barriers or their mediating effects on performance require a clear explanation (Wang, Lin, \& Li, 2010).

Internal activities of innovation refer to those that are based on the use of internal capabilities, internalized knowledge, while external activities refer to the activities associating with external sources (Cassiman \& Veugelers, 2006; Chen \& Yuan, 2007; Serrano-Bedia, López-Fernández, \& García-Piqueres, 2012). The mediating effects of innovation activities on the innovation-performance (including product innovation) relationship, such as the acquisition of new knowledge, are well confirmed (Yang, Lin, Chan, \& Sheu, 2010; Hashi \& Stojcic, 2013; Gunday, Ulusoy, Kilic, \& Alpkan, 2011). However, the importance of KMP in different specific industries and its impact on innovation is still unclear (Jensen, Johnson, Lorenz, \& Lundvall, 2007; OECD, 2011).

Innovation activities increase a firm's ability to develop new resources and capabilities (Frenz \& Letto-Gillies, 2009). Relying on external innovation activities may direct firms from exploitation to the exclusion of exploration. These firms are likely to become effective in the short term but self-destructive in the long term (Serrano-Bedia, López-Fernández, \& García-Piqueres, 2012). The values of external sources of innovation based on alliance diversity can be affected by the technology intensity of the industries (Cassiman \& Veugelers, 2006) or environmental dynamism (Wang, Lin, \& $\mathrm{Li}, 2010)$. The family businesses tend to pursue lower innovation inputs as they are more sensitive to uncertain activities and to protect their share right than non-family firms, even if they can be more efficient in generating innovation outputs (Duran, Kammerlander, Van Essen, \& Zellweger, 2016). For enhancing innovation performance, firms in high-tech industries require more human and internal relational capitals. In contrast, firms in low-tech industries require more structural capital (Buenechea-Elberdin, Kianto, \& Sáenz, 2018). Entrepreneurial capital may be more critical to hightech firms, while renewal capital is more important to low-tech firms. Therefore, we expect that the knowledge and innovation management activities for firms in different industrial contexts (such as high-tech or low-tech industries) would be distinctive (Reboud, Mazzarol, \& Soutar, 2014), which warrants further studies.

\subsection{Innovation Activities in China Industries}

Innovation patterns of firms vary among regions, cultures, organizations and technology intensities (Law, Lau, \& Ip, 2019; Kirner, Kinkel, \& Jaeger, 2009).

High-tech firms spend largely on intramural R\&D (Hirsch-Kreinsen, 2008; Heidenreich, 2009), while the sources of innovation in low-tech industries are usually exogenous (Hertog, Bergman, \& Charles, 2001). In high-tech firms, information sources are generally internal sources, whereas lowtech firms are external (Law, Lau, \& Ip, 2019).

Besides information sources for innovation, high- and low- tech firms are also with different human capitals. Large firms rely on the capabilities of individuals in creating new products, improving product quality and acquiring resources. However, small and medium enterprises (SME) rely more 
Table 1. Comparison of knowledge and innovation practices between high-tech and low tech in China

\begin{tabular}{|l|l|l|}
\hline & \multicolumn{1}{|c|}{ High-tech } & \multicolumn{1}{c|}{ Low-tech } \\
\hline Category & $\begin{array}{l}\text { Medical \& Pharmaceutical Products; } \\
\text { Manufacture of Aircraft \& Spacecraft; } \\
\text { Manufacture of electronics \& telecom } \\
\text { equipment; computer \& office equipment and } \\
\text { Manufacture of Medical and \& Measuring } \\
\text { Instruments }\end{array}$ & $\begin{array}{l}\text { Household appliances, the food industry, the } \\
\text { paper, publishing and print industries, wood and } \\
\text { furniture, the manufacture of metal products and } \\
\text { the plastic products }\end{array}$ \\
\hline $\begin{array}{l}\text { Sources of } \\
\text { information }\end{array}$ & $\begin{array}{l}\text { Internal sources within the enterprise group, } \\
\text { components or software }\end{array}$ & $\begin{array}{l}\text { External sources such as suppliers of equipment, } \\
\text { materials }\end{array}$ \\
\hline $\begin{array}{l}\text { Innovation } \\
\text { behavior }\end{array}$ & $\begin{array}{l}\text { Large firms, according to individual capability, } \\
\text { create new products to improve product quality } \\
\text { and to capture the resources needed; } \\
\text { Small firms rely heavily on imitation of } \\
\text { foreign technology rather than on indigenous } \\
\text { innovation; }\end{array}$ & $\begin{array}{l}\text { Venture into high-tech process technologies; or } \\
\text { simply based on diffused innovation generated } \\
\text { in the high-tech sectors. }\end{array}$ \\
\hline $\begin{array}{l}\text { Knowledge } \\
\text { practices }\end{array}$ & $\begin{array}{l}\text { Knowledge resources captured by large firms } \\
\text { depend on development needs for the future, } \\
\text { knowledge sources from internal; } \\
\text { Small firms rely more on collective learning and } \\
\text { external knowledge sources; }\end{array}$ & $\begin{array}{l}\text { Facing new concerns, such as knowledge } \\
\text { sources, knowledge dissemination where the } \\
\text { sources could be from the high-tech sectors. }\end{array}$ \\
\hline
\end{tabular}

on collective learning, by referring to or imitating external sources, such as imitation of foreign technology rather than on indigenous innovation (Wang, Lin, \& Li, 2010; Barbieri, Di Tommaso, \& Huang, 2010).

In China, the major factors leading to significant innovation performance among high-tech firms include government's support and investment, acquiring knowledge sources and technology transfer (Sun \& Du, 2010; Cheung, 2010).

On the other hand, many low-tech firms in China ventured into the high-tech process and technologies (Santamaria, Nieto, \& Barge-gie, 2009). These companies include manufacturers in the food industry, paper, publishing and print industries, and many other products such as furniture, metal products and plastic products (Hirsch-Kreinsen, 2008; Lee, Choy, \& Chan, 2014; Lee, Tse, Ho, \& Choy, 2015). There are several barriers concerning the innovation processes of low-tech firms, including the knowledge-base, knowledge carriers, knowledge sharing, and innovation capability. Both high- and low-tech sectors have their specifics in innovation (See Table 1).

\subsection{Knowledge Management Practices In China Industries}

Knowledge management practices (KMP) is impactful on innovation performance. Effective KMP leads to effective innovation capacity (Donate \& Sánchez de Pablo, 2015; Sofiyabadi, Valmohammadi, \& Sabet Ghadam, 2020. It affects innovation performance by connecting R\&D efforts, new idea generation and innovations (Zack, McKeen, \& Singh, 2009). Effective management of market or employee knowledge also improves innovation performance.

Knowledge management practices result in the supply of competencies and required capacities to empower the organization (value creation) through knowledge discovery and novel methods. Knowledge management functions develop innovation capacities and functional outcomes. Applying knowledge management practices like creating and sharing knowledge leads organizations to growth, innovation, the creation of new business models, and the creation of the proper position in their industry (Valmohammadi, Sofiyabadi, \& Kolahi, 2019; Ode \& Ayavoo, 2020).

For example, a previous study in the Australia and New Zealand region among high-tech manufacturing companies showed that KMP contributes to innovation performance when a 
simultaneous approach of soft human resource management practices and problematic information technology practices are implemented (Donate \& Sánchez de Pablo, 2015). Another study among high-tech SME in the pharmaceutical industry showed the positive effects of KMP practices on innovation performance (Alegre, Sengupta, \& Lapiedra, 2013).

However, KMP in China can be different on whether the firm is high-tech or low-tech. Hightech firms focus more on new product-related innovations, whereas low-tech firms are more on the services, such as introducing innovative manufacturing technologies or implementing innovation concepts (Law, Lau, \& Ip, 2019). High-tech firms are more adaptive to develop dynamic KMP (Shang, Lin, \& Wu, 2009). Innovation and knowledge created in the high-tech sectors diffuse into the low-tech sectors (Robertson \& Patel, 2007). However, low-tech firms are faced with problems concerning the innovation processes, including the capability in knowledge, carriers of knowledge and the dissemination of knowledge (Cheung, 2010).

Though it has been proven that there are correlations between KMP and innovation, the effects of them with innovation sources and activities on innovation performance are still unclear while comparing in the high-tech and low-tech industrial contexts. This study thus explores how KMP affects product innovation performance in the context of China manufacturing in both types of industries. The research questions are, therefore:

- How do KMP impact product innovation in the industries in China?

- How do the low-tech firms differ from the high-tech firms in China regarding the KMP and innovation performance?

\section{RESEARCH MODEL}

In this study, a structured equation model is proposed to study the impact of innovation sources, innovation activities, KMP, and intellectual property (IP) usage on product innovation performance (Figure 1).

Innovation sources refer to the external sources of innovation actively acquired by the firms. Innovation activities in this study refer to the internal innovation activities of the firms. These activities include $R \& D$ and corresponding innovation processes. The proposed research model incorporates IP and KMP, and new product sales measure product innovation performance.

In general, innovation activities have positive effects on product innovation performance and have relationships with access to external sources (Cassiman \& Veugelers, 2006; Chen \& Yuan, 2007; Serrano-Bedia, López-Fernández, \& García-Piqueres, 2012; Hashi \& Stojcic, 2013). Extant literature in general shows that multiple innovation sources help firms generate new, diverse knowledge that can be adopted, simulated, and integrated for different innovation activities, leading to better new product performance. When the firms seek information and ideas from external parties like customers, suppliers, universities, research institutions, government/public authorities, consultants, the press, or trade fairs (OECD , 2010), the collected information can be used to improve learning-by-using/doing/ sharing and experimentation for product innovation (Sharif, Baark, \& Lau, 2012).

The abundant lead user literature has further suggested that customer or user is a major source of innovation for product innovation (Marzi, Ciampi, Dalli, \& Dabic, 2020; Bigliardi, Ferraro, Filippelli, \& Galati, 2020). When a user/customer acts as a source of innovation collaborating with the firm in innovation activities, the firm can better understand customer needs by recognizing and exploiting more innovation opportunities, acquiring and co-creating knowledge with the customers. These lead to better product concepts for breakthrough innovation (Brem, Bilgram, \& Gutstein, 2018; Schweisfurth, 2017; Lettl, Hienerth, \& Gemuenden, 2008). Some lead users can pave the way for radical innovations launching in the marketplace (Roy, 2018).

With diverse innovation sources obtained, internal R\&D can improve a firm's ability to create and absorb new internal and external knowledge for innovation (Sharif, Baark, \& Lau, 2012). External R\&D 


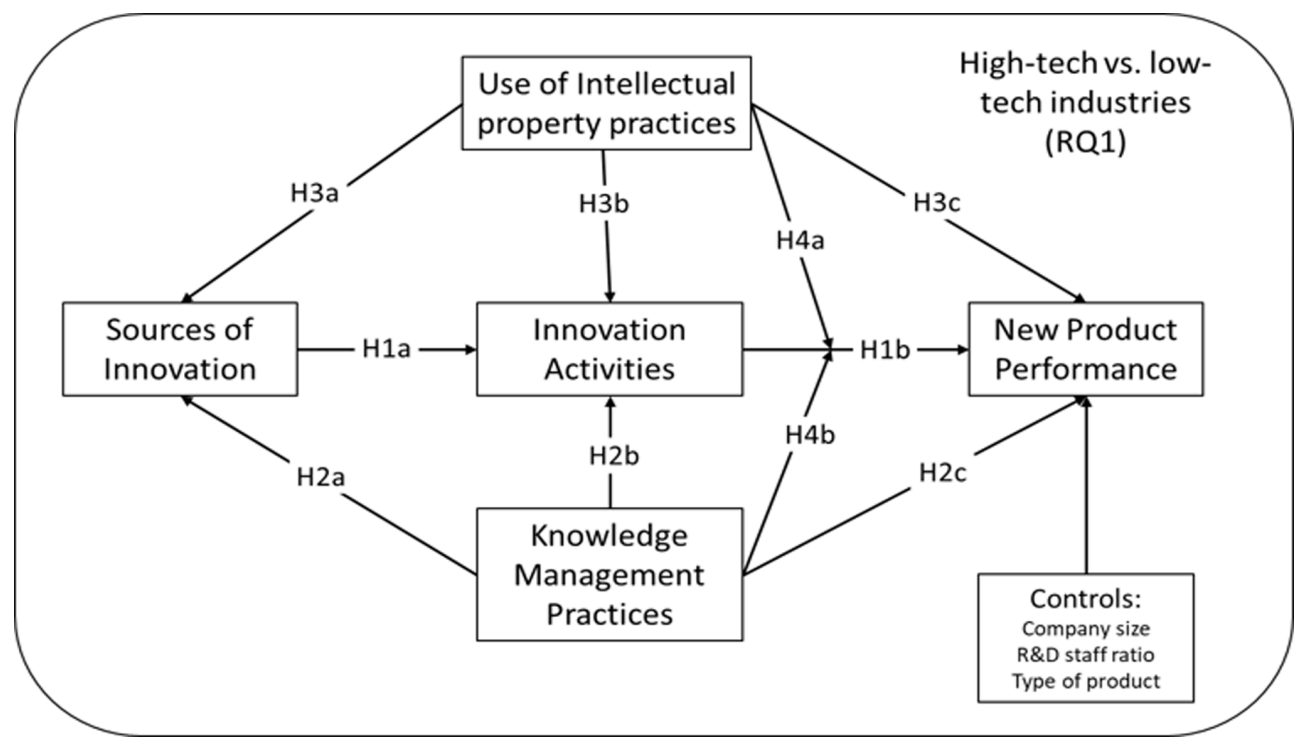

activities improve external knowledge sharing and collaborative innovation activities, leading to better innovation performance (Wang \& Hu, 2020). The acquisition of external knowledge helps increase the knowledge stock for recombinative innovation and enlarge the possible experimental innovation solutions (Papa, Dezi, Gregori, Mueller, \& Miglietta, 2018). Adopting machinery, equipment, and other capital goods helps develop new production processes for incremental innovation (Pavitt, 1984). Other preparations for innovation activities facilitate product commercialisation and export new products or processes that motivate firms to innovate (Baldwin \& Johnson, 1996).

However, existing literature on knowledge relatedness and innovation has not considered the significant difference between high and low-tech industries. Empirical analyses of knowledge search pattern and firms' innovation are exclusively based on either high-tech industries or the whole manufacturing industries (Wu \& Wang, 2017). Hence, little has been known about the knowledge search pattern and innovation of low-tech firms. Comparatively, high-tech industries, low-tech industries are easily subject to price competition and costs rather than inventions. Low tech industries are generally focused on incremental innovation rather than radical innovation and may rely on innovation sources (Grillitsch, 2015). While this relationship can be well-studied, We would like to study how innovation sources and activities affect new product performance among low-tech and high-tech firms. It is thus hypothesized:

H1a: Innovation sources are positively correlated with innovation activities H1b: Innovation activities are positively correlated with new product performance

The integration of different sources of knowledge and information relating to the new product development process is critical to the knowledge management practices of new product innovation (Marzi, Ciampi, Dalli, \& Dabic, 2020). Knowledge management practices (KMP) are closely related to product innovation performance. These practices include how the team level knowledge is managed and the learning processes within the new product project teams. Researches have confirmed the linkage between team learning and new product success, while team level learning is integral in the KMP of new product teams (Akgün, Byrne, Keskin, \& Lynn, 2006; Akgün, Lynn, \& Yilmaz, 2006; 
Akgün, Byrne, Keskin, \& Lynn, 2005). It would be crucial to understand how the knowledge is acquired, accumulated and applied in the new product innovation processes.

KMP is found to impact product innovation performance and proven to be associated with innovation performance by connecting R \& R\&D efforts (Zack, McKeen, \& Singh, 2009). Effective KMP helps to share or distribute new knowledge acquired from innovation sources to the relevant internal units, which increase the opportunity for product innovation. The KMP can also streamline the innovation activities by creating a database for the interior units to identify and acquire internal and external knowledge for innovation (Shang, Lin, \& Wu, 2009). These efforts can be considered as innovation activities that involve corresponding innovation sources.

Innovation in low-tech industries can be fulfilled merely by in-house R\&D activities (internal knowledge search) that does not require advanced external technology (Hirsch-Kreinsen, 2008). Recent studies pointed out that innovation of low-tech firms does not depend on formal (internal) R\&D activities but activities such as design, the use of advanced machinery and training as well as external sources of knowledge and information (Cheung, 2010). A study carried out in 2012 found that external rather than internal knowledge search exerted a significant influence on product innovation of low-tech enterprises (Grillitsch, 2015).

To further explore whether KMP can help both high-tech and low-tech firms improve product innovation in a significant way, it is hence hypothesized:

H2a: KMP is positively correlated with innovation sources

$\mathrm{H} 2 \mathrm{~b}$ : KMP is positively correlated with innovation activities

$\mathrm{H} 2 \mathrm{c}$ : KMP is positively correlated with new product performance

The literature reviewed is limited in content to hypothesize that the use of IP practices impacts product innovation performance, despite the potential contribution of intellectual property (Tidd, 2017). In general, firms with effective IP practices can secure and capitalize on the innovation outputs. They may be encouraged to invest in sourcing new ideas and conducting various innovation activities. Intellectual property (IP) is viewed in innovation management research as an indicator or proxy for innovation inputs or outputs, e.g. patents or licensing income, or in innovation management practice, as a means of protecting knowledge. Lee et al. (2018) reports that, under technologically complex industries, multiple IP protection mechanisms can complementarily improve product innovation performance, but, under technologically simple industries, the mechanisms may substitute with each other that diminish their effects on innovation. Also, patent usage may not be effective for product sales in traditional industries (Agostini, Filippini, \& Nosella, 2016). However, according to a structural literature review, Pedro et al. (2018) report insufficient large-scaled empirical research in the field of IP and the consequences of IP management. The effect of IP usage on firm performance may depend on the company's strategy and capabilities with the institutional environment, which require further studies (Grzegorczyk, 2020).

Considering that IP is often adopted in knowledge creation, we would thus like to explore if the use of IP has an impact on innovation activities as well the new product performance in both hightech and low-tech context:

H3a: Use of IP is positively correlated with innovation sources

$\mathrm{H} 3 \mathrm{~b}$ : Use of IP is positively correlated with innovation activities

H3c: Use of IP is positively correlated with new product performance

Following the same logic, we suggest that both KMP and the use of IP can enable firms to share, integrate and secure their knowledge to enhance their innovation capability (Wu \& Wang, 2017; Tidd, 2017). The KMP and IP usage can be used to protect the innovation outputs generated by innovation 
activities, promote innovation activities by specifying valuable information and rewards for the R\&D participants, and enhance the new product performance by appropriately appropriating the outcomes of innovation activities (Bican, Guderian, \& Ringbeck, 2017). While IP is an asset to the firm, we propose that IP usage affects innovation activities but may not mainly result from the innovation activities for three reasons. Firstly, some companies may conduct innovation activities for creating new products directly without using IP protections when time-to-market is critical, the IP regime is weak, or the firm's ability to protect the IP is limited. Secondly, the IP usage may refer to different IP strategies (e.g. offensive, defensive, preventive or leveraging) and management approaches (e.g. the use of market power, licensing, cooperation, donation, etc.) (Grzegorczyk, 2020), which do not directly result from the innovation activities. For example, Chirico et al. (2020) report that the adoption of patent protection may depend on the family ownership structure. Instead, the effective combination of IP protection mechanisms can directly affect product innovation performance (Lee, Joo, \& Kim, 2018), as we hypothesized above. Finally, while more innovation activities may relate to more adoption of IP, such adoption plays a critical role for the innovation activities initially, not consequentially, as the IP may be used for deciding an appropriation for starting innovation collaborations (Guo-Fitoussi, Bounfour, \& Rekik, 2019), for example, reported that IP rights could complement with innovation activities to improve a firm's productivity. Similar reasons may apply for KMP as well. Thus, we further hypothesize that:

H4a: Use of IP does partially moderate the effect on the relationship between innovation activities and new product performance

H4b: KMP does partially moderate the effect on the relationship between innovation activities and new product performance

\section{METHODOLOGY}

\subsection{Measures}

The questionnaire applied the 7-point Likert scale, where level 7 corresponds to the strongly-agree category and level 1 to the strongly-disagree category. The 7-point Likert scale was used as it was perceived as a quick and practical but reliable rating scale (Preston \& Colman, 2000). The Fourth Community Innovation Survey (CIS4) questionnaire design was adapted to measure sources of knowledge management (Law, Lau, \& Ip, 2019).

Having verified the validity of the constructs through extensive data collection and multiple pilot studies. The finalized constructs are shown in the Appendix. Three items: 'sales due to new-to-market products', 'sales due to new-to-firm products' and 'sales due to marginally modified products' were introduced to measure product innovation performance (Law, Lau, \& Ip, 2019). These output-based innovation measures have been continuously advised to measure a company's product innovation performance in the OSLO Manual 2018 (European Communities, 2018), and literature (Law, Lau, \& Ip, 2019; Lau \& Lo, 2019).

$R \& D$ intensity of participating companies and the ratio of the $R \& D$ expenditure to the turnover are asked to identify where the participating company is a high- or low- tech firm. According to an OECD study (OECD , 2002), a 5\% R\&D intensity is a proxy for identifying high-tech. While we were not able to collect actual R\&D intensity data due to confidentially, we managed to ask the respondents to identify their company as either: annual R\&D intensity over 5\% as high-tech companies (i.e. semiconductor manufacturing, electronics manufacturing, or other high-tech industries), or yearly R\&D intensity less than $5 \%$ as non-hi-tech companies. T-tests were carried out on the R\&D staff ratio between high-tech and non-hi-tech firms, and a partially significant difference is found $(\mathrm{t}=-1.918$, p-value $=0.057<0.10)$. 
Four control variables were added in this study. First, the industry type was added to control industry-specific effects (Hock-Doepgen et al., 2020). Different industries may also have different emphasizes on knowledge management practices (Wu \& Hu, 2018). Company size in terms of employee numbers was controlled as it might be correlated with technological innovation performance as large firms would have more resources/inertia (Hock-Doepgen et al., 2020) or competition (Wu \& $\mathrm{Hu}, 2018$ ) for knowledge management activities. Firm innovation capacity in terms of R\&D staff ratio was controlled as R\&D investment tended to impact a firm's innovation performance (Tsai, 2001). The types of product in terms of consumer and industrial products were considered new product success related to the product types (Fang, 2011).

Multiple pilot studies were carried out to finalize the survey questionnaire. Three academics in technological innovation were primarily consulted to ensure a high level of content validity and improve the survey instrument. A pilot study of ten (10) specialists working in manufacturing industries in China were interviewed to revise the questionnaire content. Another pilot study of a pre-test of the revised questionnaire was conducted with thirty (30) managers from China manufacturing firms. They were asked to complete the questionnaire and comment on the clarity and appropriateness of the items in the questionnaire. The readability of items measurements was confirmed. The overall process of the questionnaire development follows the guideline suggested by Flynn et al. (1990) and Cooper and Schindler (2003).

\subsection{Data Collection}

Stratification of random sampling was adopted in this study based on the size and principal activity of the sampled companies. Data was collected from manufacturers in both the high-tech and low-tech industries in China.

Fudan University assisted the selection of participating companies in China in Mainland China. Selected firms were in the manufacturing industry officially registered in China.

The targeted respondents were the presidents, general managers, directors of engineering, $R \& D$ managers, or engineering managers to ensure that the respondents are sufficient to respond to the questions. Face-to-face interviews or direct contact were administered by the Fudan University in China (from September 2017 to March 2018). Among the 1200 invitations sent, 152 responses were obtained, at a response rate of $17.7 \%$. While this response rate is relatively low, it is similar to other innovation studies (Sharif, Baark, \& Lau, 2012; Papa, Dezi, Gregori, Mueller, \& Miglietta, 2018; Zhang, Qi, Wang, Pawar, \& Zhao, 2018). Also, the low response rates tend to be a characteristic of the industrial survey in Asian countries, as manufacturers might worry about information leaking or be too busy to answer it (Cai et al., 2015; Wang et al., 1998). To reduce the respondent bias and comply with an ethical standard, responses were voluntarily, and respondents were anonymous. The sample profile is shown in Table 2.

Table 2. All the respondents were at the senior managerial level with direct responsibilities with the topic concerned. The seniority level of respondents supported the credibility of the data. They include the presidents, general managers, engineering directors, $R \& D$ managers and engineering managers. Regarding the business nature, it shows that $4.4 \%, 31.1 \%, 38.5 \%$ and $25.9 \%$ of the respondents were in semiconductor manufacturing, and electronics manufacturing and other hightech industries, respectively. The ratio of consumer products and industrial products is 6:4. Most of participating companies are small in size, $71.1 \%$ of them had fewer than 200 employees, while only $3.9 \%$ had more than 1000 employees. Approximately $28 \%$ of the respondent companies worked in R\&D activities, and over 50\% had at least university degrees.

We conducted a non-response bias test by comparing the early and late respondents among the research constructs. Still, the results were insignificant, showing that non-response bias may not be a severe problem in this study. Common method variance was addressed in two stages. First, procedurally, the measurements of the research constructs were located in different parts of the questionnaire to achieve psychological and methodological separation. The respondents were allowed 
Table 2. Sample profile

\begin{tabular}{|c|c|c|}
\hline & $\mathbf{N}$ & Valid percentage $(\%)$ \\
\hline \multicolumn{3}{|l|}{ Type of industry* } \\
\hline Semiconductor manufacturing & 6 & $4.4 \%$ \\
\hline Electronics manufacturing & 42 & $31.1 \%$ \\
\hline Other high-tech industries & 52 & $38.5 \%$ \\
\hline Other than high-tech & 35 & $25.9 \%$ \\
\hline \multicolumn{3}{|l|}{ Company size* } \\
\hline$<50$ & 43 & $33.6 \%$ \\
\hline $51-199$ & 48 & $37.5 \%$ \\
\hline $200-699$ & 27 & $21.1 \%$ \\
\hline $700-999$ & 5 & $3.9 \%$ \\
\hline$>=1000$ & 5 & $3.9 \%$ \\
\hline \multicolumn{3}{|l|}{ Product types* } \\
\hline Consumer products & 59 & $59.6 \%$ \\
\hline Industrial products & 39 & $39.4 \%$ \\
\hline \multicolumn{3}{|l|}{ Type of firms } \\
\hline \multirow[t]{2}{*}{$\begin{array}{l}\text { High-tech firms (R\&D ratio>5\%) } \\
\text { Low-tech firms (R\&D ratio<5\%) }\end{array}$} & $\begin{array}{c}117 \\
35\end{array}$ & $\begin{array}{l}77 \% \\
23 \%\end{array}$ \\
\hline & & Mean (S.D.) \\
\hline Ratio of R\&D staff & & $27.83 \%(20.60)$ \\
\hline Ratio of university degree or above in $R \& D$ & & $58.32 \%(29.45)$ \\
\hline \multicolumn{3}{|l|}{ Respondent positions* } \\
\hline President or vice president & 2 & $1.5 \%$ \\
\hline General Manager and Director & 4 & $3.1 \%$ \\
\hline Manager & 79 & 60.3 \\
\hline Engineering Specialists & 46 & $35.1 \%$ \\
\hline
\end{tabular}

Note: * the total is smaller than the 152 effective responses due to missing data. Since they are not the research constructs, so we keep using them as control variables.

to be anonymous when answering the questions to avoid social desirability bias. Second, statistically, our Partial Least Squares (PLS) model showed that no outer or inner variance inflation factor (VIF) value was more extensive than 3.3, suggesting that the collinearity problems might not be severe in this study (Sharif, Baark, \& Lau, 2012). We also conducted the Harman one-factor test that the first factor accounted for $45.39 \%$, which is less than $50 \%$, suggesting that the common method bias might not be very severe. 
Furthermore, we used the first factor to create a common method factor to adjust the PLS model testing (OECD, 2010; Liang, Saraf, Hu, \& Xue, 2007). The original PLS model adding the method factor had the same statistical findings as to the original one without the method factor. The variance of innovation sources, innovation activities, and new product performance remained significant as $\mathrm{R}^{2}=0.32,0.55$ and 0.26 . Furthermore, according to Lindell and Whitney (2001) 's marker variable approach, in our short questionnaire, we identified a theoretically and empirically unrelated variable (i.e. the respondent's position) as a marker and correlated it with our original model. The correlations among all the latent variables and the marker were much less than 0.3 , and the variance of the research constructs remained significant as $\mathrm{R}^{2}=0.35,0.56$ and 0.34 correspondingly. These results suggested that the common method bias might not be serious in this study. Theoretically, as one of the main focus of our research is to test the moderation effects (H4 and RQ1), prior literature showed that common method bias could not inflate, but deflate, such moderating effect because the bias could not constitute any statistically significant outcomes observed (Podsakoff et al., 2012).

\subsection{Results and Findings}

\subsubsection{Data Analysis}

To examine the research hypotheses, we adopted Partial Least Squares (PLS) structural equation modelling with the SmartPLS 3.0 version(Hair Jr, Hult, Ringle, \& Sarstedt, 2017; Tashiro, Lau, Mori, Fujii, \& Kajikawa, 2012; Marcoulides, Chin, \& Saunders, 2009). Similar to the covariancebased methods (Schweisfurth, 2017), this approach simultaneously estimates both measurement and structural models. The PLS approach also eases the impact of constraints, including the parametric assumptions, sample size requirements, model complexity, exploratory and confirmatory research, and factor indeterminacy (Vinzi, Chin, Henseler, \& Wang, 2010). PLS is particularly useful for our study due to the limited amount of data and the exploratory nature of the study. Its estimation method is robust when the model is complex with correlated variables or non-normal data (Peng \& Lai, 2012). Still, the PLS parameter estimates could have more bias and inconsistency than the covariance-based analysis. Considering the model complexity for mediation, moderation and a two-group analysis in a relatively small sample size available, the adoption of PLS is justified (Chin, 2010). The model testing partially follows the rule of thumb of a minimum of 5 cases per predictor (Hair, Hollingsworth, Randolph, \& Chong, 2017) and detect a minimum $\mathrm{R}^{2}$ of 0.1 for a statistical power of $80 \%$ (with a $10 \%$ probability of error) (Bentler \& Chou, 1987). In PLS modelling, SmartPLS3.0 was used to examine the research hypotheses, and a two-stage approach was used to examine the proposed moderation effects (Hair Jr, Hult, Ringle, \& Sarstedt, 2017). statistically significant at p-value less than 0.001

Table 3 shows the reliability and validity results. Cronbach's alpha over a cutoff point of 0.7 , composition reliability over 0.6 and the AVE over 0.5 was perceived acceptable for analysis (Cohen, n.d.). Discriminant validity was deemed to be acceptable because the squared root of the AVE of each research construct exceeded the correlations of all the other constructs (Fornell \& Larcker, 1981), the heterotrait-monotrait ratios of the correlations were less than 0.90 (Henseler et al., 2015). The collinearity statistics of all measurement items (i.e. VIF) were lower than 5 (Hair Jr, Hult, Ringle, $\&$ Sarstedt, 2017). The high correlations among the variables are understandable as they are all related to what a company should do to innovate, and their concepts are highly related theoretically. Still, they are statistically discriminant, and their correlations are below 0.8 , which are acceptable in conducting PLS-SEM modelling.

Figure 2 shows the PLS model results. The variance of the innovation sources, innovation activities and new product performance is given by $\mathrm{R}^{2}=0.35,0.56$ and 0.34 , respectively. To determine the contribution of the independent variables (i.e. use of IP practices and knowledge management practices) being added into the model, the effect of size was calculated (Peng \& Lai, 2012). It was assessed by inputting $\mathrm{R}^{2}$ of the models, with and without the independent variables, using Cohen's (1992) effect size formula: 
Table 3. Correlation, Reliability and validity Results

\begin{tabular}{|c|c|c|c|c|c|c|c|c|c|c|}
\hline & Mean & S.D. & SI & IA & NPP & UIP & KMP & AVE & Alpha & CR \\
\hline $\begin{array}{l}\text { Sources of } \\
\text { innovation (SI) }\end{array}$ & 3.37 & 1.71 & 0.79 & & & & & 0.62 & 0.58 & 0.86 \\
\hline $\begin{array}{l}\text { Innovation } \\
\text { activities (IA) }\end{array}$ & 3.46 & 1.70 & 0.54 & 0.84 & & & & 0.70 & 0.89 & 0.90 \\
\hline $\begin{array}{l}\text { New product } \\
\text { performance } \\
(\mathrm{NPP})\end{array}$ & 3.31 & 1.25 & 0.38 & 0.52 & 0.88 & & & 0.78 & 0.72 & 0.88 \\
\hline $\begin{array}{l}\text { Use of IP } \\
\text { practices (UIP) }\end{array}$ & 3.43 & 1.79 & 0.56 & 0.66 & 0.43 & 0.81 & & 0.65 & 0.82 & 0.88 \\
\hline $\begin{array}{l}\text { Knowledge } \\
\text { management } \\
\text { practices (KMP) }\end{array}$ & 3.88 & 1.74 & 0.53 & 0.70 & 0.44 & 0.71 & 0.85 & 0.72 & 0.87 & 0.88 \\
\hline
\end{tabular}

Note: CR: Composite reliability, AVE: Average variance explained, Alpha: Cronbach's alpha. Multi-item reflective constructs were adopted in this study. Diagonal elements are the square root of AVE.

How knowledge management practices affect new product performance

- A study of high- and low- tech manufacturers in China

Figure 2. Path Model (a whole sample)

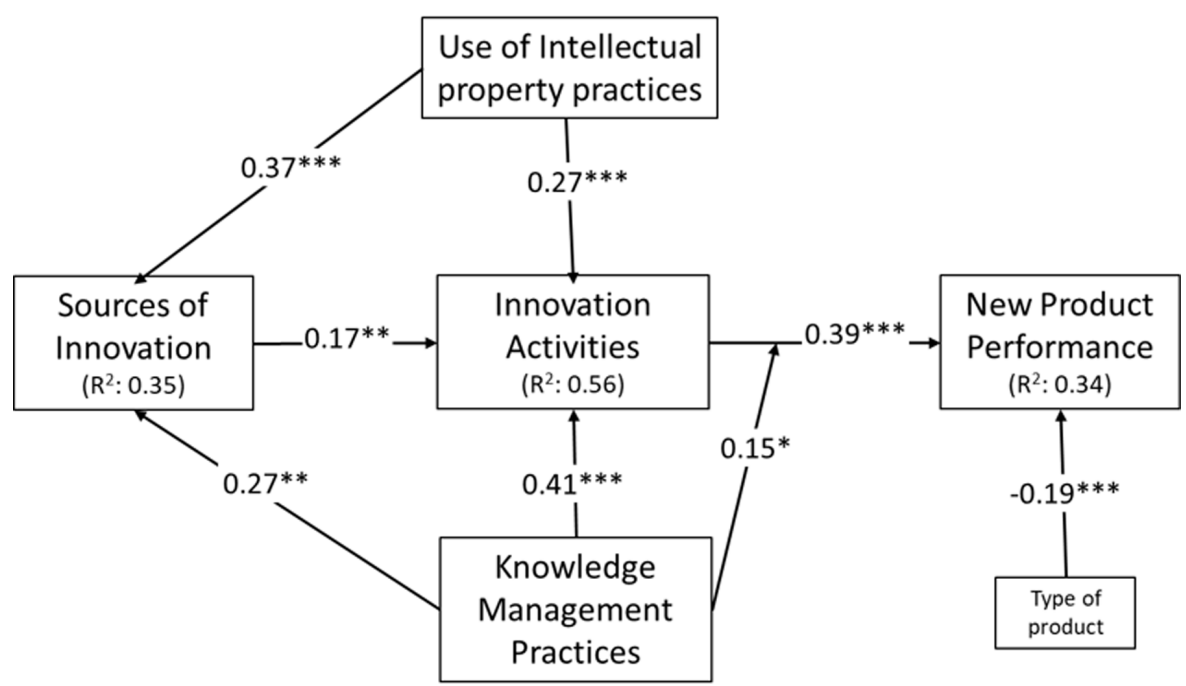

Effect size $\mathrm{R}^{2}$ in innovation activities $=(0.56-0.30) /(1-0.56)=0.59$

Effect size $\mathrm{R}^{2}$ in new product performance $=(0.34-0.31) /(1-0.34)=0.05$

The values for the effect size of $0.02,0.15$ or 0.35 indicate weak, moderate or large effects of the model variables, respectively. Our model had an effect size between 0.05-0.59, which suggests an acceptable explanatory power in the study.

On the other hand, as PLS path modelling does not provide a widely accepted global model fit (Hair Jr, Hult, Ringle, \& Sarstedt, 2017), we cautiously adopted the Standardized Root Mean Square Residual (SRMR) approach to assess the model fit. Our model has an SRMR value of 0.079 in the estimated model, which is slightly lower than the cutoff point of 0.08 (Hair Jr, Hult, Ringle, \& Sarstedt, 


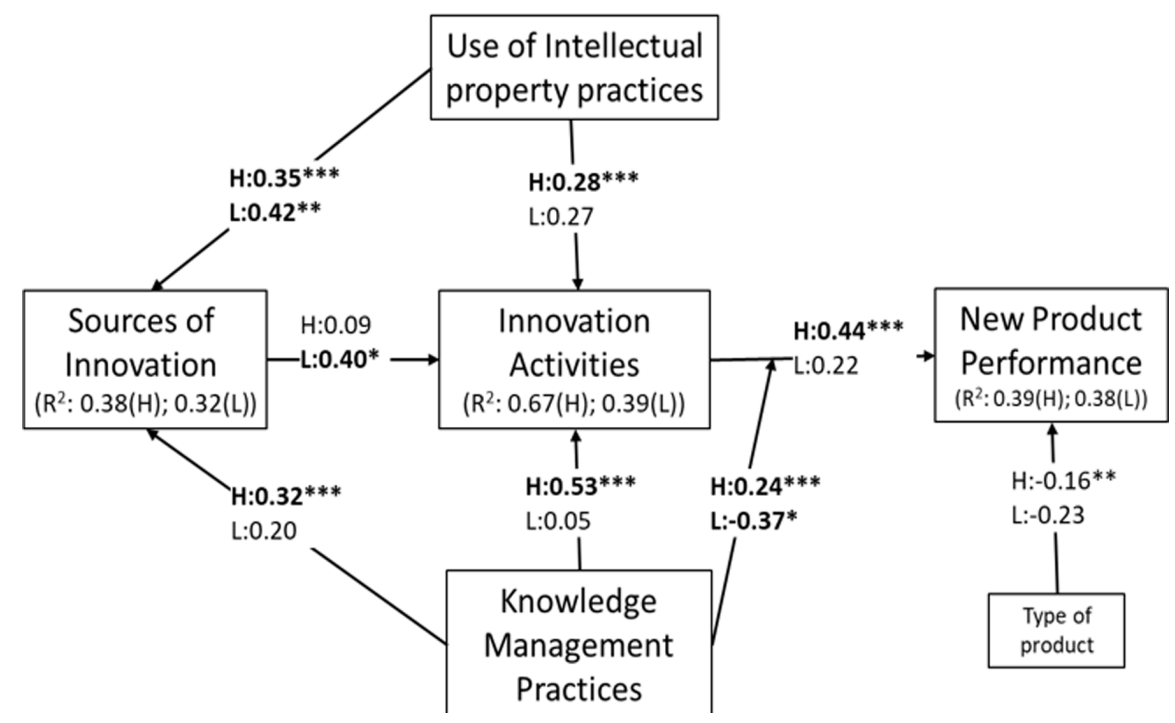

2017). Thus, the overall model fit seems to be acceptable. On the other hand, an alternative model that links KMR and IP usage as mediators between innovation activities and new product performance was tested with a poor SRMR value of 0.102 in the estimated model. The variance of the innovation sources, innovation activities and new product performance were lower than our original model as $\mathrm{R}^{2}$ $=0.30,0.49$ and 0.33 , respectively. This result further supports our model in Figure 2. A bootstrapping approach of 200, 500, 1000 and 5000 random samples of observations were used for calculating the significance and stability of the coefficient values. Figure 2 shows the path coefficients and p-values for the statistically significant relationships among the research variables. Non-significant relationships were deleted for model parsimony. The path coefficients represent the means of the re-samples, and the t-statistics (p-value) were generated from a bootstrap resample of 500. The significance of the path coefficients of the resample of 5000 was consistent with other resample numbers. The PLS model showed that the sources of innovation are positively correlated with innovation activities $(b=0.17$, $\mathrm{p}$-value $<0.05)$; innovation activities are positively correlated with new product performance $(b=0.39$, p-value $<0.01$ ); knowledge management practices are positively correlated with sources of innovation $(b=0.27, p$-value $<0.05)$ and innovation activities $(b=0.41$, $p$-value $<0.01)$; The use of IP practices is positively correlated with innovation activities $(b=0.37$, $p$-value $<0.01)$ and innovation activities $(b=0.27$, p-value $<0.05)$; and knowledge management practices interact with innovation activities to positively affect new product performance $(b=0.15$, p-value $<0.10)$ (See Figure 4$)$. Therefore, hypotheses $1 \mathrm{ab}, 2 \mathrm{ab}, 3 \mathrm{ab}$ and $4 \mathrm{~b}$ are supported. But, hypotheses $2 \mathrm{c}, 3 \mathrm{c}$ and $4 \mathrm{a}$ are not supported.

To explore the roles of high-tech and low-tech industries on the research model, multiple group analysis was conducted by using the PLS-MGA approach (Chin, 2010). Figure 3 shows the exploratory result of PLS modelling in this study. For high-tech firms, it was found that the moderating effect of knowledge management practices on the relationship between innovation activities and new product performance becomes highly significant $(b=0.44, p$-value $<0.01)$ (See also Figure $3-c$ ), but the relationship between sources of innovation and innovation activities becomes insignificant $((b=0.09, p$-value $<0.10)$. However, we found a direct effect of innovation sources on new product performance $(b=0.21, p$-value $<0.05)$. Here, we added a direct link from the innovation sources to new product performance and re-ran the path model and multi-group analysis, generating statistical results consistent with our tested model in Figure 2-b. For low-tech firms, we found that knowledge management practices become insignificant to innovation activities $(b=0.05, p$-value $<0.10)$ and 
Figure 4. Simple slope analysis of KMP moderation effect (a whole sample)

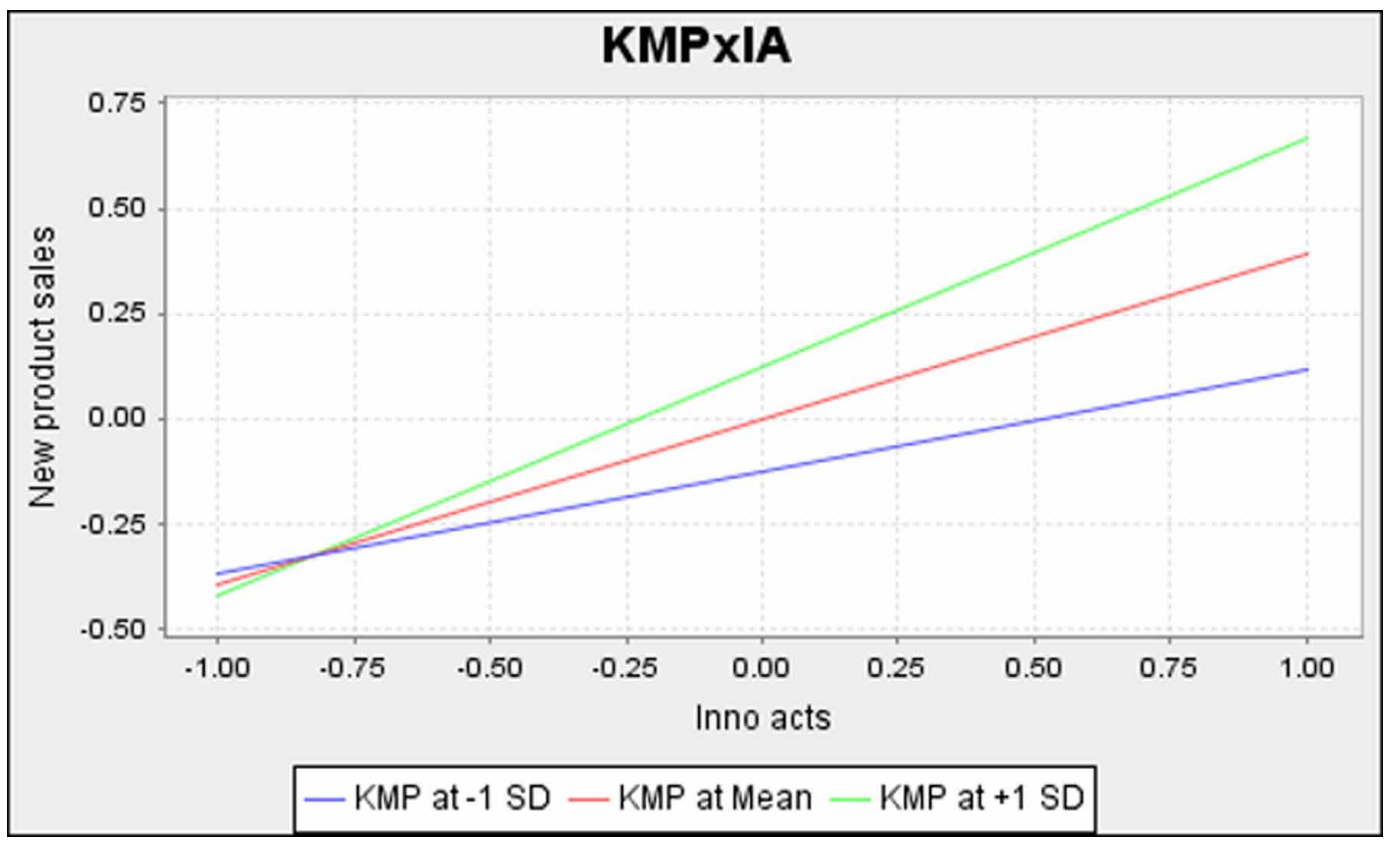

Figure 5. Simple slope analysis of KMP moderation effect (high-tech firms only)

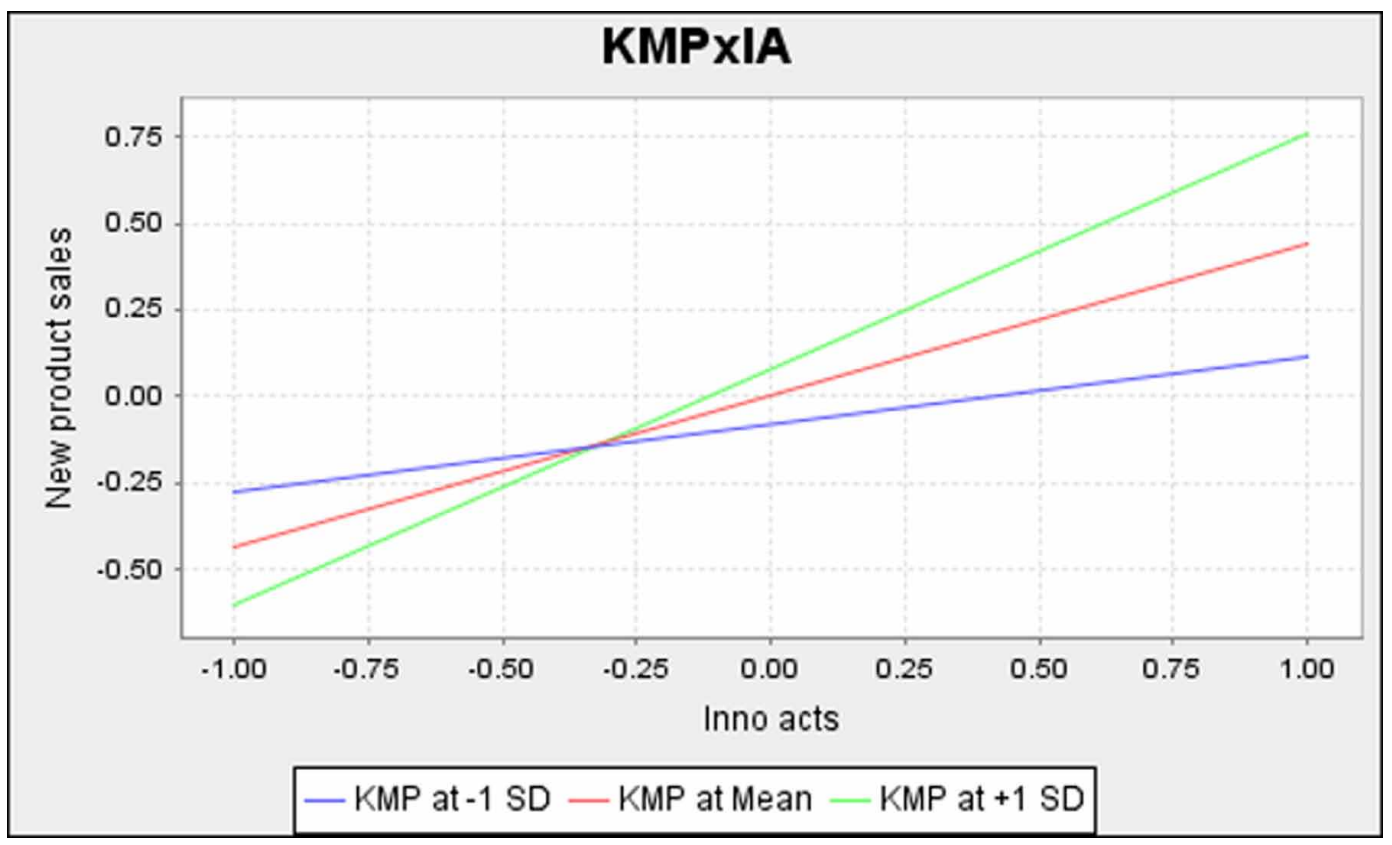




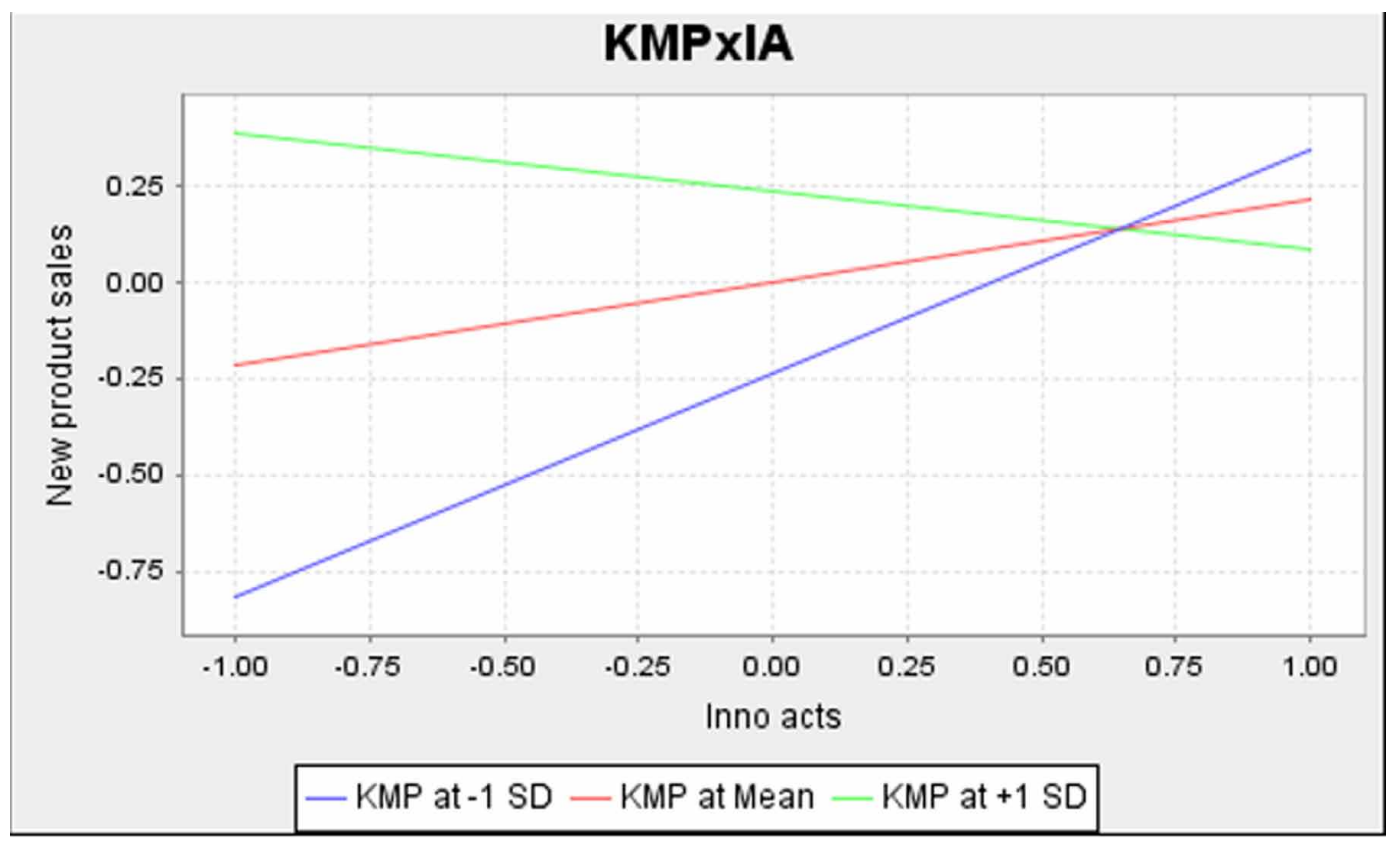

sources of innovation $(b=0.20, p$-value $<0.10)$. The use of IP practices also becomes insignificant to innovation activities $(b=0.27$, $\mathrm{p}$-value $<0.01)$. This finding, in general, suggests that some knowledge management and IP practices are less effective for low-tech firms in creating new saleable products. However, this interpretation should be seen as cautious since, in this study, the sample size of the lowtech firms was only 35, which may be not sufficient for the PLS modelling analysis of this complex model. Thus, though the findings of low-tech firms are interesting, further studies are necessary to conduct a similar comparative analysis with a larger sample size.

\section{DISCUSSION}

\subsection{Factors of Product Innovation Performance and Moderation Effects of KMP}

The results suggest that, by controlling the R\&D staff ratio, company size and type of product, innovation sources, KMP and the use of IP are positively correlated with innovation activities, which are positively correlated with new product performance (NPP) (see Figure 2). The KMP also affects NPP indirectly by interacting with innovation activities (See Figure 4). Hypotheses 1ab, 2ab, $3 a b$ and $4 \mathrm{~b}$ are supported, whereas $2 \mathrm{c}, 3 \mathrm{c}$ and $4 \mathrm{a}$ are not supported. NPP is directly affected by innovation activities but not KMP and the use of IP, whilst KMP imposes a moderation effect on the relationship between innovation activities and NPP. Thus, the results show that investment in KMP may not directly affect NPP. Instead, KMP significantly affects innovation activities, which, in return, affects NPP.

Among the factors in the proposed model, KMP is the only factor that directly affects innovation activities and a moderation effect. Simultaneously, KMP imposes the highest coefficient of significance towards both innovation sources and innovation activities. The dual effect by KMP shows that KMP is indispensable in the entire new product innovation process. Furthermore, KMP was marginally significant to moderate the relationship between product innovation activities and performance in general. Still, such moderation is highly substantial for high-tech firms but not low-tech firms. These findings are reasonable as high-tech firms tend to deal with higher levels of market uncertainties 
and technological complexities in product innovation, so KMP would be more important for them to build different types of internal and externally diverse knowledge for product innovation (BuenecheaElberdin et al., 2018; Martinez et al., 2017).

\subsection{Difference Between High-Tech and Low-Tech}

KMP was found to have moderating effects on the relationships between innovation activities and new product performance. It is also interesting to note that the moderating effect of KMP is highly significant among high-tech firms, while innovation sources also significantly affect NPP directly. However, for low-tech firms, the direct effects of KMP on innovation sources and activities are not significant, and the moderating effect of KMP on the relationship between innovation activities and NPP is only marginally supported (Figure 3 ).

Regarding high-tech firms only, the sources of innovation have no significant effect on innovation activities. In contrast, both KMP and IP use have substantial effects on innovation activities and impose significant direct effects on new product performance $(b=0.44)$. However, it is different among low-tech firms, where innovation activities are solely affected by sources of innovation that are positively affected by IP use. However, no significant correlation between innovation activities and new product performance is shown. This implies that most investments in KMP do not have much effect or just an indirect effect (via sources of innovation) on the innovation activities, similar to the use of IP practices. The phenomenon found that KMP and IP usage may not be very effective for low-tech firms in China manufacturing.

The difference in results found in high-tech and low-tech firms is likely due to the potential 'firm' culture, nature of products and the 'acceptance and adoption' of knowledge management practices. Understandably, low-tech firms may not legitimately accept KMP and its formal adoption in accordance with the 'low-tech' nature. It may be because low-tech firms do not depend on formal (internal) R\&D activities, but activities such as design, the use of advanced machinery and training as well as external sources of knowledge and information, whilst high-tech firms may adopt in-house innovation (Cheung, 2010). In some previous studies, internal knowledge was found exerting a significant influence on product innovation of low-tech enterprises, but not external knowledge (Grillitsch, 2015); this may be the reason for the effect of KMP is found insignificant among low-tech firms.

\section{CONCLUSION}

This paper presents an empirical study on the exploration of how knowledge management practices, including the sources of knowledge management, affect the product innovation performance in the context of China, in both the low- and high- tech industries. Specifically, we examine how sources of knowledge management and relevant practices affect product innovation performance.

KMP is the only factor having a direct effect on innovation activities and a moderating effect and imposes the highest coefficient significance towards both innovation sources and innovation activities. The dual effect of KMP is thus indispensable in the entire new product innovation process, and the moderating effect of KMP is highly significant among high-tech firms. However, both the direct and indirect effects of KMP are insignificant among low-tech firms.

\subsection{Contributions}

This study confirms the positive influence of innovation activities on new product performance (H1). The results confirm the effect of KMP and the use of IP on innovation activities and performance $(\mathrm{H} 2$, $\mathrm{H} 3$ ) and the moderating effect of KMP (H4). This empirical study thus marks significant progress in research on the moderating effect of KMP in the relationship between innovation activities and new product performance. More importantly, we show the significant difference between high-tech and low-tech firms regarding the direct and moderating effects of KMP on product innovation activities 
and performance. The focus on the issue of high- and low- tech companies and their comparison in the context of China is the novelty of this study.

Our finding is consistent with recent studies that innovation activities are closely related to knowledge linkages and internal R\&D intensity (OECD, 2002; Ringle, Sarstedt, \& Straub, 2012; Cao, Zeng, Teng, \& Si, 2018). Compared to high-tech firms, the effect of KMP among low-tech firms is found insignificant (Cheung, 2010). This may imply that low-tech firms have a more urgent need to construct a close relationship with their suppliers, customers and competitors for external knowledge sources and as well as internal KMP activities (Wu \& Wang, 2017; Kanchana, Law, Comepa, Malitjhong, \& Phusavat, 2011). Besides, the KMP and IP uses are found a significant difference between high- and low-tech firms. Interestingly, IP uses among low-tech firms are insignificant in product innovations. The results bring about implications to the IP uses in low-tech firms, and thus it may be unnecessary to have a high IP level among low-tech firms.

Furthermore, since low-tech firms constitute a significant part of the sector, our findings suggest that low-tech firms need an industrial environment that favours cooperation, communication and interactions among firms (Wu \& Wang, 2017; Phusavat, Kess, Law, \& Kanchana, 2010).

Future research can focus more on the low-tech sector in different cultural contexts, such as geographical areas and product types. While the current sample size is sufficient for the PLS analysis, more empirical data is preferred. Further studies should collect more empirical data in China, which can be difficult due to the sensitivity of company innovation data.

\subsection{Limitation of The Study}

Similar to other empirical studies, there are several limitations and opportunities for further studies. First, this study is limited to the use of a single key informant approach for data collection. While we believe that the respondents were knowledgeable in answering the questions, further research may adopt the multiple informant approach, which can be challenging to complete in developing countries like China. Since our survey data is limited to 152 Chinese manufacturers, the generalizability of our findings is limited to China manufacturers in the sampled industries. While our measurement is valid, the sample population is relevant to our study, and the number of data is sufficient for the PLS modelling and meets the effect size requirements, a more extensive scaled empirical studies would be recommended to replicate our research. The cross-sectional data used in the present study cannot validate causal relationships among the variables. The common method bias issues could not be ignored even if our post-hoc statistical results suggest no significant bias in the empirical findings. Furthermore, the limited sample size in this study does not allow us to conduct more complex moderated mediation models (say, decomposing innovation activities as a single factor into a list of activities, each of which is tested to affect innovation performance in the model). Finally, this study is limited with a relatively low response rate of an industrial survey in China manufacturing sectors.

\section{ACKNOWLEDGMENT}

This work was supported by the Deakin University Research Fund (Start-up Research K Law). The research is also partially supported by a grant from the Hong Kong Polytechnic University, Department of Industrial and Systems Engineering (H-ZG3K) and the National Research Foundation of Korea Grant funded by the Korean Government (MOE) (NRF-2016S1A2A2912137). 


\section{REFERENCES}

Abbate, T., Cesaroni, F., \& Presenza, A. (2020). Knowledge transfer from universities to low-and mediumtechnology industries: Evidence from Italian winemakers. The Journal of Technology Transfer, 1-28. doi:10.1007/ s10961-020-09800-X

Agostini, L., Filippini, R., \& Nosella, A. (2016). Protecting intellectual property to enhance firm performance: Does it work for SMEs? Knowledge Management Research and Practice, 14(1), 96-105. doi:10.1057/ kmrp.2014.20

Akgün, A. E., Byrne, J., Keskin, H., \& Lynn, G. S. (2006). Transactive Memory System in New Product Development Teams. IEEE Transactions on Engineering Management, 53(1), 95-111. doi:10.1109/ TEM.2005.857570

Akgün, A. E., Byrne, J., Keskin, H., Lynn, G. S., \& Imamoglu, S. Z. (2005). Knowledge networks in new product development projects: A transactive memory perspective. Information \& Management, 42(8), 1105-1120. doi:10.1016/j.im.2005.01.001

Akgün, A. E., Lynn, G. S., \& Yilmaz, C. (2006). Learning process in new product development teams and effects on product success: A socio-cognitive perspective. Industrial Marketing Management, 35(2), $210-224$. doi:10.1016/j.indmarman.2005.02.005

Alegre, J., Sengupta, K., \& Lapiedra, R. (2013). Knowledge management and innovation performance in a hightech SMEs industry. International Small Business Journal, 31(4), 454-470. doi:10.1177/0266242611417472

Baldwin, J. R., \& Johnson, J. (1996). Business strategies in more- and less-innovative firms in Canada. Research Policy, 25(5), 785-804. doi:10.1016/0048-7333(95)00875-6

Barbieri, E., Di Tommaso, M. R., \& Huang, M. (2010). Industrial Development Policy and Innovation in Southern China: Government Targets and Firms Behaviour. European Planning Studies, 18(1), 83-106. doi:10.1080/09654310903343542

Bender, G. (2008). How to grasp innovativeness of organizations: outline of a conceptual tool. In H. HirschKreinsen \& D. Jacobson (Eds.), Innovation in Low-tech Firms and Industries (pp. 25-42). Edward Elgar. doi: $10.4337 / 9781848445055.00010$

Bentler, P. M., \& Chou, C. P. (1987). Practical issues in structural modeling. Sociological Methods \& Research, 16(1), 78-117. doi:10.1177/0049124187016001004

Berchicci, L., Tucci, C. L., \& Zazzara, C. (2013). The influence of industry downturns on the propensity of product versus process innovation. Industrial and Corporate Change, 23(2), 429-465. doi:10.1093/icc/dtt011

Bican, P. M., Guderian, C. C., \& Ringbeck, A. (2017). Managing knowledge in open innovation processes: An intellectual property perspective. Journal of Knowledge Management, 21(6), 1384-1405. doi:10.1108/JKM11-2016-0509

Bigliardi, B., Ferraro, G., Filippelli, S., \& Galati, F. (2020). The influence of open innovation on firm performance. International Journal of Engineering Business Management, 12. Advance online publication. doi:10.1177/1847979020969545

Brem, A., Bilgram, V., \& Gutstein, A. (2018). Involving lead users in innovation: A structured summary of research on the lead user method. International Journal of Innovation and Technology Management, 15(03), 1850022. doi:10.1142/S0219877018500220

Breznik, K. (2016). Using social network analysis to identify innovation clusters. International Journal of Innovation and Learning, 19(3), 272-285. doi:10.1504/IJIL.2016.075654

Brookfield, J., Liu, R. J., \& MacDuffie, J. P. (2008). Taiwan's bicycle industry A-Team battles Chinese competition with innovation and cooperation. Strategy and Leadership, 36(1), 14-19. doi:10.1108/10878570810840643

Buenechea-Elberdin, M., Kianto, A., \& Sáenz, J. (2018). Intellectual capital drivers of product and managerial innovation in high-tech and low-tech firms. $R \&$ D Management, 48(3), 290-307. doi:10.1111/radm.12271 
Cai, L., Yu, X., Liu, Q., \& Nguyen, B. (2015). Radical innovation, market orientation, and risk-taking in Chinese new ventures: An exploratory study. International Journal of Technology Management, 67(1), 47-76. doi:10.1504/IJTM.2015.065896

Cao, X., Zeng, G., Teng, T., \& Si, Y. (2018). The best spatial scale of firm innovation networks: Evidence from Shanghai high-tech firms. Growth and Change, 49(4), 696-711. doi:10.1111/grow.12252

Cassiman, B., \& Veugelers, R. (2006). In search of complementarity in innovation strategy. Management Science, 52(1), 68-82. doi: $10.1287 / \mathrm{mnsc} .1050 .0470$

Chai, K. H., Yap, C. M., \& Wang, X. (2011). Network closure's impact on firms' competitive advantage: The mediating roles of knowledge processes. Journal of Engineering and Technology Management, 28(1-2), 2-22. doi:10.1016/j.jengtecman.2010.12.001

Chen, Y., \& Yuan, Y. (2007). The innovation strategy of firms: Empirical evidence from the Chinese high-tech industry. Journal of Technology Management, 2(2), 145-153. doi:10.1108/17468770710756095

Cheung, K. Y. (2010). Spillover effects of FDI via exports on innovation performance of China's high-technology industries. Journal of Contemporary China, 19(65), 541-557. doi:10.1080/10670561003666152

Chin, W. W. (2010). How to write up and report PLS analyses. Handbook of partial least squares, 655-690. doi:10.1007/978-3-540-32827-8_29

Chirico, F., Criaco, G., Baù, M., Naldi, L., Gomez-Mejia, L. R., \& Kotlar, J. (2020). To patent or not to patent: That is the question. Intellectual property protection in family firms. Entrepreneurship Theory and Practice, 44(2), 339-367. doi:10.1177/1042258718806251

Cohen, J. (1992). A power primer. Psychological Bulletin, 112(1), 155-519. doi:10.1037/0033-2909.112.1.155 PMID:19565683

Cooper, D. R., \& Schindler, P. S. (2003). Business research methods (8th ed.). McGraw-Hill.

Donate, J. D., \& Sánchez de Pablo, J. D. (2015). The role of knowledge-oriented leadership in knowledge management practices and innovation. Journal of Business Research, 68(2), 360-370. doi:10.1016/j. jbusres.2014.06.022

Duran, P., Kammerlander, N., Van Essen, M., \& Zellweger, T. (2016). Doing more with less: Innovation input and output in family firms. Academy of Management Journal, 59(4), 1224-1264. doi:10.5465/amj.2014.0424

Fang, E. E. (2011). The Effect of Strategic Alliance Knowledge Complementarity on New Product Innovativeness in China. Organization Science, 22(1), 158-172. doi:10.1287/orsc.1090.0512

Flor, M. L., Oltra-Mestre, M. J., \& Sanjurjo, E. L. (2019). An analysis of open innovation strategies in firms in low and medium technology industries. IEEE Transactions on Engineering Management. Advance online publication. doi:10.1109/TEM.2019.2911253

Flynn, B. B., Sakakibara, S., Schroeder, R. G., Bates, K. A., \& Flynn, E. J. (1990). Empirical research methods in operations management. Journal of Operations Management, 9(2), 250-284. doi:10.1016/0272-6963(90)90098-X

Frenz, M., \& Letto-Gillies, G. (2009). The impact on innovation performance of different sources of knowledge: Evidence from the UK Community Innovation Survey'. Research Policy, 38(7), 1125-1135. doi:10.1016/j. respol.2009.05.002

Grillitsch, M. (2015). Variety in knowledge sourcing, geography and innovation: Evidence from the ICT sector in Austria. Papers in Regional Science, 94(1), 25.

Grzegorczyk, T. (2020). Managing intellectual property: Strategies for patent holders. The Journal of High Technology Management Research, 31(1), 100374. doi:10.1016/j.hitech.2020.100374

Gunday, G., Ulusoy, G., Kilic, K., \& Alpkan, L. (2011). Effects of innovation types on firm performance. International Journal of Production Economics, 133(2), 662-676. doi:10.1016/j.ijpe.2011.05.014

Guo-Fitoussi, L., Bounfour, A., \& Rekik, S. (2019). Intellectual property rights, complementarity and the firm's economic performance. International Journal of Intellectual Property Management, 9(2), 136-165. doi:10.1504/ IJIPM.2019.100213 
Hair, J., Hollingsworth, C. L., Randolph, A. B., \& Chong, A. Y. L. (2017). An updated and expanded assessment of PLS-SEM in information systmes research. Industrial Management \& Data Systems, 117(3), 442-458. doi:10.1108/IMDS-04-2016-0130

Hair, J. F. Jr, Hult, G. T. M., Ringle, C., \& Sarstedt, M. (2017). A Primer on Partial Least Squares Structural Equation Modeling (PLS-SEM) (2nd ed.). Sage Publications.

Hashi, I., \& Stojcic, N. (2013). The impact of innovation activities on firm performance using a multi-stage model: Evidence from the community innovation survey 4. Research Policy, 42(2), 353-366. doi:10.1016/j. respol.2012.09.011

Heidenreich, M. (2009). Innovation patterns and location of European low-and medium-technology industries. Research Policy, 38(3), 483-494. doi:10.1016/j.respol.2008.10.005

Hekkert, M. P., Suurs, R. A. A., Negro, S. O., Kuhlmann, S., \& Smits, R. E. H. M. (2006). Functions of innovation systems: A new approach for analysing technological change. Technological Forecasting and Social Change, 74(4), 413-432. doi:10.1016/j.techfore.2006.03.002

Hernandez-Vivanco, A., Bernardo, M., \& Cruz-Cázares, C. (2016). Relating open innovation, innovation and management systems integration. Industrial Management \& Data Systems, 116(8), 1540-1556. doi:10.1108/ IMDS-09-2015-0405

Hertog, P. D., Bergman, E. M., \& Charles, D. (2001). Creating and sustaining innovation cluster: towards a synthesis, Innovative Cluster Drivers of National Innovation Systems. OECD.

Hirsch-Kreinsen, H. (2008). "Low-Technology”: A forgotten sector in innovation policy. Journal of Technology Management, 3(3), 11-20. doi:10.4067/S0718-27242008000100002

Hock-Doepgen, M., Clauss, T., Kraus, S., \& Cheng, C. F. (2020). Knowledge management capabilities and organizational risk-taking for business model innovation in SMEs. Journal of Business Research. Advance online publication. doi:10.1016/j.jbusres.2019.12.001

Hong, J., Feng, B., Wu, Y., \& Wang, L. (2016). Do government grants promote innovation efficiency in China's high-tech industries? Technovation, 57, 4-13. doi:10.1016/j.technovation.2016.06.001

Jensen, M. B., Johnson, B., Lorenz, E., \& Lundvall, B. A. (2007). Forms of knowledge and modes of innovation. Research Policy, 36(5), 680-693. doi:10.1016/j.respol.2007.01.006

Kanchana, R., Law, K. M. Y., Comepa, N., Malitjhong, P., \& Phusavat, K. (2011). Interrelationships among knowledge management, organisational learning and innovation. International Journal of Innovation and Learning, 9(2), 145-162. doi:10.1504/IJIL.2011.038541

Kirner, E., Kinkel, S., \& Jaeger, A. (2009). Innovation paths and the innovation performance of lowtechnology firms- An empirical analysis of German Industry. Research Policy, 38(3), 447-458. doi:10.1016/j. respol.2008.10.011

Lau, A. K., \& Lo, W. (2019). Absorptive capacity, technological innovation capability and innovation performance: An empirical study in Hong Kong. International Journal of Technology Management, 80(1-2), 107-148. doi:10.1504/IJTM.2019.099750

Law, K. M. Y., Lau, A. K., \& Ip, W. H. (2019). What drives success in product innovation? Empirical evidence in high-tech and low-tech manufacturers in China. International Journal of Technology Management, 79(2), 165-198. doi:10.1504/IJTM.2019.097525

Lee, C. K. H., Choy, K. T., \& Chan, Y. N. (2014). A knowledge-based ingredient formulation system for chemical product development in the personal care industry. Computers \& Chemical Engineering, 65, 40-53. doi:10.1016/j.compchemeng.2014.03.004

Lee, C. K. H., Tse, Y. K., Ho, G. T. S., \& Choy, K. L. T. (2015). Fuzzy association rule mining for fashion product development. Industrial Management \& Data Systems, 115(2), 383-399. doi:10.1108/IMDS-09-2014-0277

Lee, J. M., Joo, S. H., \& Kim, Y. (2018). The complementary effect of intellectual property protection mechanisms on product innovation performance. $R \&$ D Management, 48(3), 320-330. doi:10.1111/radm.12296 
Lettl, C., Hienerth, C., \& Gemuenden, H. G. (2008). Exploring how lead users develop radical innovation: Opportunity recognition and exploitation in the field of medical equipment technology. IEEE Transactions on Engineering Management, 55(2), 219-233. doi:10.1109/TEM.2008.919717

Liang, H., Saraf, N., Hu, Q., \& Xue, Y. (2007). Assimilation of enterprise systems: The effect of institutional pressures and the mediating role of top management. Management Information Systems Quarterly, 31(1), 59-87. doi: $10.2307 / 25148781$

Lindell, M. K., \& Whitney, D. J. (2001). Accounting for common method variance in cross-sectional research designs. The Journal of Applied Psychology, 86(1), 114-121. doi:10.1037/0021-9010.86.1.114 PMID:11302223

Love, J. H., \& Roper, S. (2015). SME innovation, exporting and growth: A review of existing evidence. International Small Business Journal, 33(1), 28-48. doi:10.1177/0266242614550190

Lyu, H., \& Zhang, Z. J. (2017). Incentives for knowledge sharing: Impact of organisational culture and information technology. Enterprise Information Systems, 11(9), 1416-1435.

Marcoulides, G. A., Chin, W. W., \& Saunders, C. (2009). A critical look at partial least squares modeling. Management Information Systems Quarterly, 33(1), 171-175. doi:10.2307/20650283

Martinez, M. G., Zouaghi, F., \& Garcia, M. S. (2017). Capturing value from alliance portfolio diversity: The mediating role of R\&D human capital in high and low tech industries. Technovation, 59, 55-67. doi:10.1016/j. technovation.2016.06.003

Marzi, G., Ciampi, F., Dalli, D., \& Dabic, M. (2020). New product development during the last ten years: The ongoing debate and future avenues. IEEE Transactions on Engineering Management.

Novak, A., Breznik, K., \& Natek, S. (2020). How leaders can initiate knowledge management in organizations: Role of leadership style in building knowledge infrastructure. Human Systems Management, 39(1), 37-50. doi:10.3233/HSM-190596

Ode, E., \& Ayavoo, R. (2020).The mediating role of knowledge application in the relationship between knowledge management practices and firm innovation. Journal of Innovation and Knowledge, 5(3).

OECD. (2002). Frascati Manual. Proposed Standard for surveys on research and experimental development (6th ed.). Paris: OECD.

OECD. (2010). The OECD Innovation Strategy: Getting a Head Start on Tomorrow. OECD.

OECD. (2010). Measuring Innovation: A New Perspective. OECD.

OECD. (2011). The OECD Innovation Strategy: Getting a Head Start on Tomorrow. OECD.

OECD. (2018). Oslo Manual 2018: Guidelines for collecting, reporting and using data on innovation. OECD Publishing.

Papa, A., Dezi, L., Gregori, G. L., Mueller, J., \& Miglietta, N. (2018). Improving innovation performance through knowledge acquisition: The moderating role of employee retention and human resource management practices. Journal of Knowledge Management, 24(3), 589-605. doi:10.1108/JKM-09-2017-0391

Pavitt, K. (1984). Sectoral patterns of technical change: Towards a taxonomy and a theory. Research Policy, 13(6), 343-373. doi:10.1016/0048-7333(84)90018-0

Pedro, E., Leitão, J., \& Alves, H. (2018). Back to the future of intellectual capital research: A systematic literature review. Management Decision, 56(11), 2502-2583. doi:10.1108/MD-08-2017-0807

Peng, D. X., \& Lai, F. (2012). Using partial least squares in operations management research: A practical guideline and summary of past research. Journal of Operations Management, 30(6), 467-480. doi:10.1016/j. jom.2012.06.002

Phusavat, K., Kess, P., Law, K. M. Y., \& Kanchana, R. (2010). Sustaining effective business value chain: Future challenges. Industrial Management \& Data Systems, 110(8), 1176-1191. doi:10.1108/02635571011077825

Podsakoff, P. M., MacKenzie, S. B., Lee, J. Y., \& Podsakoff, N. P. (2003). Common method bias in behavioural research: A critical review of the literature and recommended remedies. The Journal of Applied Psychology, 88(5), 879-903. doi:10.1037/0021-9010.88.5.879 PMID:14516251 
Podsakoff, P. M., MacKenzie, S. B., \& Podsakoff, N. P. (2012). Sources of method bias in social science research and recommendations on how to control it. Annual Review of Psychology, 63(1), 539-569. doi:10.1146/annurevpsych-120710-100452 PMID:21838546

Preston, C. C., \& Colman, A. M. (2000). Optimal number of response categories in rating scales: Reliability, validity, discriminating power, and respondent preferences. Acta Psychologica, 104(1), 1-15. doi:10.1016/ S0001-6918(99)00050-5 PMID:10769936

Reboud, S., Mazzarol, T., \& Soutar, G. (2014). Low-tech vs high-tech entrepreneurship: A study in France and Australia. Journal of Innovation Economics \& Management, 14(2), 121-141. doi:10.3917/jie.014.0121

Ringle, C. M., Sarstedt, M., \& Straub, D. W. (2012). Editor's Comments: A Critical Look at the Use of PLSSEM. Management Information Systems Quarterly, 36(1), 1. doi:10.2307/41410402

Robertson, P. L., \& Patel, P. R. (2007). New wine in old bottles: Technological diffusion in developed economies. Research Policy, 36(5), 708-721. doi:10.1016/j.respol.2007.01.008

Roy, R. (2018). Role of relevant lead users of mainstream product in the emergence of disruptive innovation. Technological Forecasting and Social Change, 129, 314-322. doi:10.1016/j.techfore.2017.09.036

Santamaria, L., Nieto, M. J., \& Barge-gie, L. A. (2009). Beyond formal R\&D: Taking advantage of other sources of innovation in low- and medium-technology industries. Research Policy, 38(3), 507-517. doi:10.1016/j. respol.2008.10.004

Schweisfurth, T. G. (2017). Comparing internal and external lead users as sources of innovation. Research Policy, 46(1), 238-248. doi:10.1016/j.respol.2016.11.002

Serrano-Bedia, A. M., López-Fernández, M., \& García-Piqueres, G. (2012). Complementarity between innovation activities and innovation performance: Evidence from Spanish innovative firms. Journal of Manufacturing Technology Management, 23(5), 557-577. doi:10.1108/17410381211234408

Shang, S. S., Lin, S. F., \& Wu, Y. L. (2009). Service innovation through dynamic knowledge management. Industrial Management \& Data Systems, 109(3), 322-337. doi:10.1108/02635570910939362

Sharif, N., Baark, E., \& Lau, A. K. (2012). Innovation activities, sources of innovation and R\&D cooperation: Evidence from firms in Hong Kong and Guangdong Province, China. International Journal of Technology Management, 59(3/4), 203-234. doi:10.1504/IJTM.2012.047244

Sofiyabadi, J., Valmohammadi, C., \& Asl, A. S. (2020). Impact of Knowledge Management Practices on Innovation Performance. IEEE Transactions on Engineering Management, 1-15. Advance online publication. doi:10.1109/TEM.2020.3032233

Sun, Y., \& Du, D. (2010). Determinants of industrial innovation in China: Evidence from its recent economic census. Technovation, 30(9-10), 540-550. doi:10.1016/j.technovation.2010.05.003

Tashiro, H., Lau, A., Mori, J., Fujii, N., \& Kajikawa, Y. (2012). E-mail networks and leadership performance. Journal of the Association for Information Science and Technology, 63(3), 600-606.

Tidd, J. (2017). Exploiting intellectual property to promote innovation and create value. Academic Press.

Trott, P., \& Simms, C. (2017). An examination of product innovation in low-and medium-technology industries: Cases from the UK packaged food sector. Research Policy, 46(3), 605-623. doi:10.1016/j.respol.2017.01.007

Valmohammadi, C., Sofiyabadi, J., \& Kolahi, B. (2019). How do knowledge management practices affect sustainable balanced performance? Mediating role of innovation practices. Sustainability, 11(18).

Vinzi, V. E., Chin, W. W., Henseler, J., \& Wang, H. (2010). Handbook of partial least squares: Concepts, methods and applications. Springer-Verlag. doi:10.1007/978-3-540-32827-8

Wang, C., \& Hu, Q. (2020). Knowledge sharing in supply chain networks: Effects of collaborative innovation activities and capability on innovation performance. Technovation, 94, 102010. doi:10.1016/j. technovation.2017.12.002

Wang, C. C., Lin, G. C. S., \& Li, G. (2010). Industrial clustering and technological innovation in China: New evidence from the ICT industry in Shenzhen. Environment \& Planning A, 42(8), 1987-2010. doi:10.1068/a4356 
Wang, P., Wee, C. H., \& Koh, P. H. (1998). Control mechanisms, key personnel appointment, control and performance of Sino-Singaporean joint ventures. International Business Review, 7(4), 351-375. doi:10.1016/ S0969-5931(98)00020-1

Wu, A., \& Wang, C. C. (2017). Knowledge Search Pattern and Product Innovation of Firms in Low and HighTechnology Industrial Clusters: A Knowledge Relatedness Perspective. Tijdschrift voor Economische en Sociale Geografie, 108(4), 488-502. doi:10.1111/tesg.12226

Wu, I.-L., \& Hu, Y.-P. (2018). Open innovation based knowledge management implementation: A mediating role of knowledge management design. Journal of Knowledge Management, 22(8), 1736-1756. doi:10.1108/ JKM-06-2016-0238

Xi, X., Zhao, J., \& Na, Q. (2019). Design of knowledge representation and measuring method for enterprise knowledge network based on task modularisation. Enterprise Information Systems. https://www.scopus.com/ inward/record.uri?eid=2-s2.0-85064664353\&doi $=10.1080 \% 2 \mathrm{f} 17517575.2019 .1605002 \&$ partnerID=40\&md5 $=4 \mathrm{c} 25 \mathrm{~b} 29115 \mathrm{~d} 88 \mathrm{e} 683 \mathrm{db} 2 \mathrm{~d} 12 \mathrm{a} 04893277$

Yam, R. C. M., William, L., Tang, E. P. Y., \& Lau, A. K. W. (2011). Analysis of sources of innovation, technological innovation capabilities, and performance: An empirical study of Hong Kong manufacturing industries. Research Policy, 40(3), 391-402. doi:10.1016/j.respol.2010.10.013

Yang, C., Lin, S., Chan, Y., \& Sheu, C. (2010). Mediated effect of environmental management on manufacturing competitiveness: An empirical study. International Journal of Production Economics, 123(2), 210-220. doi:10.1016/j.ijpe.2009.08.017

Zack, M., McKeen, J., \& Singh, S. (2009). Knowledge management and organizational performance: An exploratory survey. Journal of Knowledge Management, 13(6), 392-409. doi:10.1108/13673270910997088

Zhang, M., Qi, Y., Wang, Z., Pawar, K. S., \& Zhao, X. (2018). How does intellectual capital affect product innovation performance? Evidence from China and India. International Journal of Operations \& Production Management, 38(3), 895-914. doi:10.1108/JJOPM-10-2016-0612

Zouaghi, F., Sánchez, M., \& Martínez, M. G. (2018). Did the global financial crisis impact firms' innovation performance? The role of internal and external knowledge capabilities in high and low tech industries. Technological Forecasting and Social Change, 132, 92-104. doi:10.1016/j.techfore.2018.01.011 


\section{APPENDIX}

Table 4. PLS Measurement Model and Measurement Items

\begin{tabular}{|c|c|}
\hline Items & $\begin{array}{c}\text { Outer } \\
\text { loading* }\end{array}$ \\
\hline \multicolumn{2}{|l|}{$\begin{array}{l}\text { Sources of innovation } \\
\text { What are the sources of knowledge and technology of your company? } \\
\text { (7-point Likert scales, } 1=\text { least frequent, } 7=\text { most frequent) }\end{array}$} \\
\hline Competitors & 0.79 \\
\hline Customers & 0.84 \\
\hline Universities, higher education institutes, government, public research institutes, private non-profit research institutes & 0.77 \\
\hline Patent disclosures & 0.75 \\
\hline Professional conference, meetings, exhibitions, professional bodies, associations, trade unions & 0.79 \\
\hline \multicolumn{2}{|l|}{$\begin{array}{l}\text { Innovation activities } \\
\text { How often does your company perform the following innovation activities? } \\
\text { (7-point Likert scales, } 1=\text { least, } 7=\text { most frequent) }\end{array}$} \\
\hline $\begin{array}{l}\text { In-house } R \& D \text { : Creative work undertaken on a systematic basis within the enterprise in order to increase the stock } \\
\text { of knowledge and use it to devise new applications. }\end{array}$ & 0.84 \\
\hline $\begin{array}{l}\text { Acquisition of extramural } R \& D \text { : Same activities as in-house } R \& D \text {, but purchased from public/private research } \\
\text { institutes or enterprises. }\end{array}$ & 0.85 \\
\hline $\begin{array}{l}\text { Acquisition of other external knowledge: Acquisition of rights to use patents \& non-patented inventions, } \\
\text { trademarks, know-how \& other types of knowledge from other enterprises \& institutions. }\end{array}$ & 0.78 \\
\hline $\begin{array}{l}\text { Acquisition of machinery, equipment and other capital goods: Acquisition of advanced machinery, equipment, } \\
\text { computer hardware/software, and land\& buildings. }\end{array}$ & 0.84 \\
\hline $\begin{array}{l}\text { Other preparations for product \& process innovations: related to the development \& implementation of product } \\
\text { and process innovations, such as design, planning \& testing and market introduction, etc. }\end{array}$ & 0.87 \\
\hline \multicolumn{2}{|l|}{$\begin{array}{l}\text { Knowledge management practices } \\
\text { How often does your company use the knowledge management practices for innovation? } \\
\text { (7-point Likert scales, } 1=\text { least, } 7=\text { most frequent) }\end{array}$} \\
\hline Develop databases of worker "best practices" & 0.82 \\
\hline Provide regular education or training programmes & 0.85 \\
\hline Promote informal and formal work teams that promote worker communication and interaction & 0.87 \\
\hline Integrate employee activities, which promotes interactions among employees from different areas & 0.84 \\
\hline \multicolumn{2}{|l|}{$\begin{array}{l}\text { Use of IP practices } \\
\text { How often does your company use the IP practices to secure innovation? } \\
\text { (7-point Likert scales, } 1=\text { least, } 7=\text { most frequent) }\end{array}$} \\
\hline Patents/copyrights & 0.82 \\
\hline Trademarks & 0.78 \\
\hline Complexity of product design & 0.82 \\
\hline Lead time advantage over competitors & 0.79 \\
\hline \multicolumn{2}{|l|}{$\begin{array}{l}\text { New product performance } \\
\text { Sales turnover due to innovation (estimated percentage share of total turnover in the last } 3 \text { years): } \\
\text { 1. }<5 \%, 2.5-10 \%, 3.10-15 \%, 4.15-20 \%, 5.20-30 \%, 6 .>30 \%\end{array}$} \\
\hline New or significantly improved goods and services introduced (new to the market) & 0.88 \\
\hline New and significantly improved goods and services introduced (new to the firm, though not new to the market) & 0.87 \\
\hline
\end{tabular}


Kris M. Y. Law is currently an Associate Professor at the School of Engineering, Deakin University, Australia. Prior to her joining Deakin University, she was a Lecturer at the Department of Industrial and Systems Engineering, Hong Kong Polytechnic University. She currently also holds a Docentship (Adjunct Professorship) in the Department of Industrial Engineering and Management, Oulu University in Finland. She undertook a post-doctoral research scholarship and was a Visiting Researcher at the Graduate Institute of Industrial Engineering, National Taiwan University in 2009-2011. Her expertise lies in organizational learning and development, technology and innovation management, technology-based entrepreneurship, project management and engineering education. She has published in journals and edited several books in the areas of performance management, organizational learning, technology and knowledge management.

Antonio K. W. Lau received the B.Sc. and Ph.D. degrees in industrial engineering and engineering management from the City University of Hong Kong, Hong Kong. He is currently an Associate Professor of operations management with the School of Management, Kyung Hee University, South Korea. He has published his work in the International Journal of Operations and Production Management, Research Policy, Journal of Product Innovation Management Journal of Cleaner Production Journal of Engineering and Technology Management, Journal of Manufacturing Technology Management and International Journal of Production Economics. His current research interests include systems of innovation, supply network analysis, supply chain management, sharing economy, and corporate social responsibility. He is the corresponding author of this paper.

W. H. Ip is Professor Emeritus of University of Saskatchewan (UoS), Canada. Prof. Ip has 30 years+ of experience in research, education, industry \& consulting. He is Adjunct Prof. of Mech. Engg in UoS, and Adjunct Prof. of Info. Engg in Shenzhen University, Visiting Prof. in South China Normal University, Civil Aviation University of China and University of Electronic Science and Technology of China; Honorary Fellow in WMG of The University of Warwick, UK, and Principal Research Fellow in the Dept of ISE of The HK Polytechnic University, China. He serves as Editor-in-Chief of EIS (T\&F) and Founding Editor of IJEBM (SAGE). 